\title{
Infrastructure Is A Key Factor For The Success Of An Entrepreneurial Business: A Case Study Of General Store Business In Gulistan-E-Jauhar, Karachi
}

\author{
Muhammad Siddique \\ PN School of Logistics \\ PNS Karsaz \\ Faraz Ahmed Wajidi \\ \& \\ Eruj Wajidi \\ Institute of Health \& Business Management (IOHBM) \\ Jinnah Sindh Medical University
}

\begin{abstract}
The part which entrepreneurs play in the economic growth of any country needs no elucidation. Having started new businesses- by utilizing their skills and knowledge- they give proliferation to new ideas in the market and reach the right decisions that serve as vehicles of prosperity and enhancement of the business. The global quest for achieving permanence in economic development and acceleration of social progress has found a new light in entrepreneurial activities. A lot of proponents such as burgeoning urbanization and industrialization, coupled with the prevalence of social legislation as well as general awareness and entrepreneurial education on formal grounds have set the stage for the everincreasing omnipresence of novel entrepreneurial ventures in various economies across the globe. This study emphasizes the need for adequate infrastructure for an entrepreneurial business, which is a key factor for the success of an entrepreneurial business. Employing a well-developed and verified scale, data collection from 100 respondents was done on a convenience basis. All of the respondents amongst whom the questionnaires were distributed to different Kariyana and general stores located in Gulistan-e-Jauhar, Karachi and descriptive statistics were applied on the relevant variables such as the importance of infrastructure, location of a business, positioning of products in a general store, similarly, use of other business techniques such as educated and trained salespersons, following to proper timing for the business, nice dealing with customers, etc. This research article aims at contributing to the existing academic literature present on the importance of infrastructure required for the better results of an entrepreneurial business. This study shall assist government regulators in making informed decisions while addressing the need and importance of adequate infrastructure for Pakistani entrepreneurs, which shall lead to more effective and well-planned initiatives, which can help not only to improve the performance of entrepreneurial ventures but also to curb and eventually eradicate poverty from Pakistan.
\end{abstract}

Keywords: Entrepreneurs, Infrastructure, General Store Business, Awareness, Respondents. 


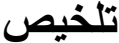

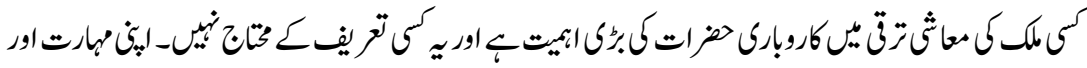

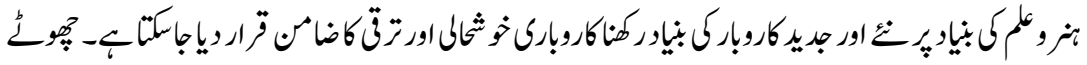

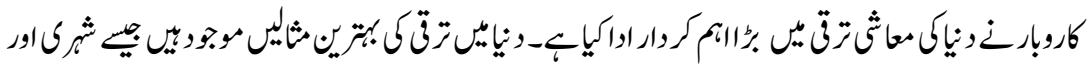

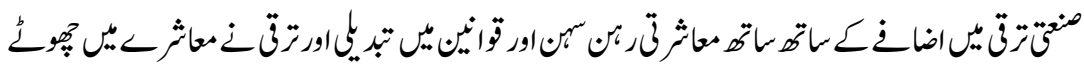

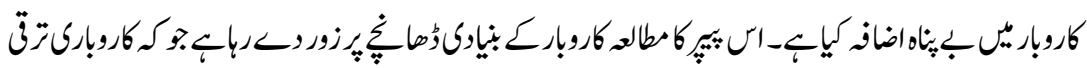

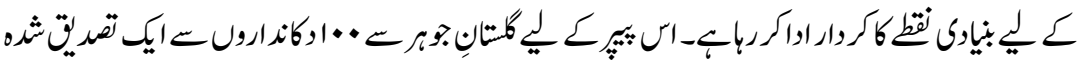

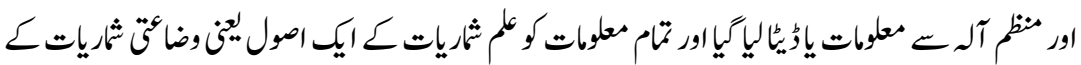

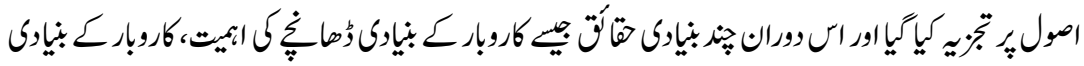

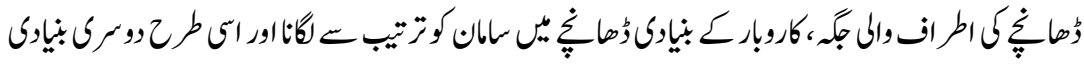

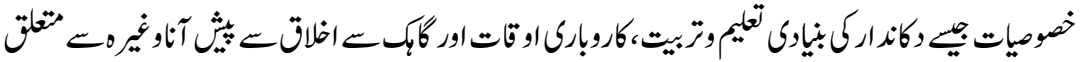

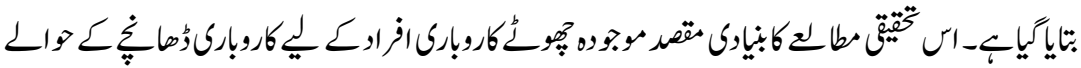

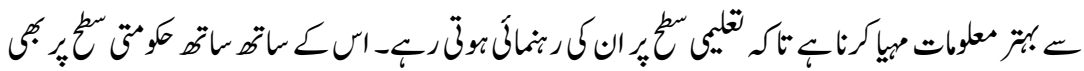

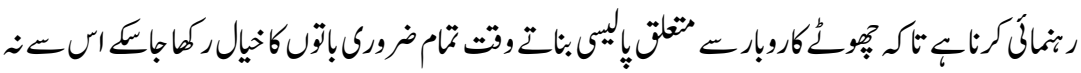

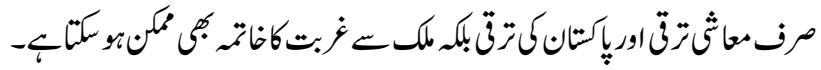

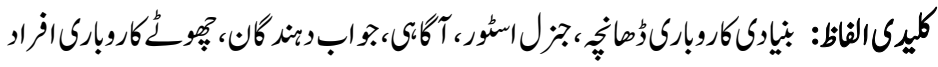

\section{Introduction}

Entrepreneurship is a term that shows the activity of setting up a business, taking on financial risks in the hope of profit. In other words, entrepreneurship is an umbrella term that assimilates under it, an activity that entails discovering, evaluating, and exploiting chances to explore new areas and new arenas for the development of the new business which incorporated a compete different setup of complete supply chain management both upstream and downstream. For more understanding it is true that entrepreneurship plays a leading role in national economies, being considered one of the main engines of economic growth, and an important contributor to creating new jobs and innovations. Entrepreneurship contributes importantly to the economy. Entrepreneurship transforms the world. Every year jobs are created and firms are brought into existence worldwide as over four million new companies are started by innovative entrepreneurs. Selling activates and competition both are increasing day by day. With the increase of population in any part of the world, the requirement of the things of daily life is 
also increasing simultaneously. Pakistan is also a populated country and Karachi is a megacity of Pakistan. The census report of 2018 says that the total population of Pakistan is to be about 202 million people and the latest population of the city of lights (Karachi) is rising at 5\% per year with a total population of 14.9 million. There are many general stores in the study area but most such setups are being undertaken by uneducated people and they do not know the importance of infrastructure for an entrepreneurial business that is a key factor for increasing the selling activities. People start their business without proper planning and the main factor involved in the financial crises that due to the huge amount of shop rent in the study area, people may not think about the adequate infrastructure and proper location of the business.

The subsequent paragraphs narrate the relevant literature that indicated the need for adequate infrastructure for an entrepreneurial. In the 3rd section, the research methodology of the study is discussed followed by the analysis of the discussion of the results. Ultimately the analysis will lead to the conclusion and hence recommendations will be drawn to add on in the body of knowledge.

\section{Research Background}

Nowadays in big cities like Karachi, a large number of people have been engaged with general and kariyana business. Most of the entrepreneurs start this business without a business background and experience. Secondly, the majority of people associated with this business are illiterate and due to the lack of awareness of the proper and adequate infrastructure for an entrepreneurial business because it a key factor for the success of such business that is why it is the utmost need to research in this field.

\section{Problem Statement}

From the data collection process, it is known that most of the entrepreneurs who are running general and kariyana business are less educated. They are unaware of the importance of proper infrastructure for an entrepreneurial business for enhancement of sales to achieve their business targets. For educating the entrepreneurs about the significance of a business proper research is essential for meeting the business requirements.

\section{Research Question}

This study will have to find out how kariyana and general store entrepreneurs can overcome their infrastructure issues and make their business more profitable. Is it true that the adequate infrastructure of an entrepreneurial business makes such business profitable? 


\section{Objectives of the Study}

Primarily, this study has the objective to create awareness among the entrepreneurs to understand the importance of infrastructure for entrepreneurial businesses especially for the businesses of kariyana and general stores so that they can minimize their business issues and can achieve their business targets easily.

\section{The Scope of the Study}

The scope of the study is to focus on the adequate infrastructure issues of entrepreneurship businesses for the success of such business units.

\section{The Significance of the Study}

The study will promote the importance of proper infrastructure for the entrepreneurial businesses for kariyana and general stores for achieving their targets easily.

\section{The Beneficiary of the Study}

Kariyana and General Store business is the most popular business in the society. A less educated person can start this business easilywith less training and money, such business may grow if it is properly managed and it is run with all the basic business needs.

\section{Limitations}

Researchers have done their utmost efforts to include the opinions of the maximum respondents (Kariyana and General Stores) to address the maximum infrastructure issues. The researchers highly depended on respondents' answers. It is observed that respondents or participants are never a hundred percent honest. There may be chances of false or wrong answers.

\section{Review of Literature}

Alhorani (2019)studied in Jordan, and disclosed the five main factors that could be substantial for an entrepreneurial business such as specialized systems and innovation, the structure of the firm, budgetary structure, advertising and efficiency, and HR structure. Bennett (2019) disclosed that environment changes can occur as a consequence of investments in physical infrastructure that not only stimulates the establishment of new businesses but also the exit of incumbent establishments. Chowdhury et al. (2019) emphasized on the adequate infrastructure of an entrepreneurship business for its success. Akinyele (2019) 
studied in Nigeriaand emphasized that the adequate portion of land, the best location, and the availability of utility facilities such as availability of electricity, gas, phone, water, and the best sewerage system is the essential arts of the adequate infrastructure of an entrepreneurial business (Greenwood et al., 2018; Mahanta \& Dr. Parbin Sultana, 2018). Diana Rusu \& Roman (2017) emphasized over the importance of infrastructure for an entrepreneurial business and its impact on the business growth. Woolley \& Woolley (2017) pointed out the latest research on entrepreneurship and infrastructure, and their research covered various realities revolving around the extent of ease with which new ventures are created and entrepreneurial success is guaranteed. The lack of essential infrastructure sets a negative impact on the functions of an SME, such as production, distribution, and selling activities. Sitharam and Hoque (2016) studied in South African, expressed that foundation factors, such as control supply and entry and, exit facilities were main concerns for adequate infrastructure in that area (Cumming \& Zahra 2016). They also pointed out that over $70 \%$ of the SMEs were facing the power supply shortage problems in the study area. They further pointed out that absent of essential utilities such as power, water, streets, and superhighways and other geological conditions increase the transportation cost of an organization. Mutsuddi (2016) explained that physical infrastructure like roads, electricity, water, land, technology etc. and it influences and enhances an organization's production irrespective of the sector to which it belongs. Rani and Sinha (2016) studied in India and (Aktar, 2016) studied in Bangladesh and, highlighted the importance of infrastructure in an SME business. Mccoy e tal. (2016) stated that infrastructure of a business provides the extra support of success for such business. Alauddin \& Chowdhury (2015) studied in Bangladesh and, found that an insufficient amount of necessary utilities, which are the part of the adequate infrastructure of an entrepreneurial business, such as, electricity, water, roads, and highways, and geographical situations affect the growth of the SME sector, and increase its transportation cost (George, Rao-Nicholson, Corbishley, \& Bansal, 2015). Agwu and Cletus Izunwanne Emeti (2014) studied in Nigeria and disclosed that $72.73 \%$ of the respondents were agreed that insufficient social infrastructures create the main challenge in the performance of the SME sector. Adisa et al. (2014) studied in Nigeria, emphasized that lack of necessary infrastructural facilities is the major issue of entrepreneurship failure. Lugo \& Espina (2014) explained the visible and invisible sub-factors of an entrepreneurial business. Among such factors the most important or the key factor is the infrastructure of such business. Secretary-General of the OECD (2013) highlighted that the proper infrastructure of a small business must include the space of business, necessary facilities, and the best available location. Ahammad \& Moudud-Ul- Huq (2013) studied in Bangladesh and explained that insufficient infrastructure is the main barrier for an entrepreneurial business (Thurik et al. 2013). Carree \& Verheul (2011) studied in the Netherlands and disclosed that lack of innovative work is not possible without proper infrastructure (Estrin \& 
Mickiewicz 2011). Lee et al. (2011) highlighted that significance of good location for an entrepreneurship business. Sabbarwal (2010)studied in India and highlighted that a lot of small businesses are running with poor infrastructure in the study area (Laclé 2010; Audretsch \& Sarkar 2010; Stephan \& Uhlaner, 2010). Haque (2007) studied in Pakistan and advised the importance of infrastructure for entrepreneurship business in Pakistan. Aldrich and Ruef (2006) indicated in their book that infrastructure of any business acts as the source of success for such business. Basil Anthony Ngwu Onugu (2005) studied in Nigeria and found that the insufficient infrastructure increases the product cost and makes them uncompetitive in the market that affects the overall business results and causes for the failure of such small and medium businesses especially in under and developing countries in the world. Grimaldi and Grandi (2005) stated that consideration of all the essential factors including the infrastructure provide a surety for the business success in future. Acs \& Varga (2004) explained that for making a business more profitable, the location of such business matters. Aschauer(1990) explored that the quality of business life remains a central focus of infrastructure for a business. Hence it is proved that the infrastructure acts as a key factor for the success of an entrepreneurial business. It means, more attractive and sufficient infrastructure is the indicator of more business. The customers visit such place more frequently where they find the attractive infrastructure because such place make ease in their buying process. Families visit such general and kariyana stores without hesitations and happily. They have more trust on such businessman who are caring. This behavior of shop-keepers, in other words, is a sign of good business relationship.

\section{Conceptual Framework}

Based on the study of relevant articles, the researcher has framed the literature review as under:

\section{Independent VariablesDependent Variable}

\section{Adequate Infrastructure $\longrightarrow$ Entrepreneurial Businesses (Kariyana \& General Stores)}

Figure-1: Conceptual Framework

\section{Hypothesis}

H1 ${ }_{0}$ Entrepreneurial Business performance have no positive association with Adequate Infrastructure.

H1 $_{\text {A }}$ Entrepreneurial Business performance have positive association with Adequate Infrastructure. 


\section{Descriptive Analysis of Alternate $\left(\mathrm{H1}_{\mathrm{A}}\right)$ Hypothesis}

It shows a strong association of entrepreneurial business performance with the availability of adequate infrastructure for such business. It means that as much as an entrepreneur does his or her business with an adequate infrastructure of such business it puts a positive impact in achieving the business targets.

\section{Research Methodology}

\section{Population}

The population of this study inhabited the Kariyana and General Stores situated in Gulistan-e-Jauhar, Karachi.

\section{Sampling Technique}

For data collection, the purposive sampling method for convenience was adopted because data was collected from where it was easy for the researchers. It is the general observation that the people who are less educated and are unaware of the significance of research hesitate to disclose their business and secondly, every entrepreneur did not participate in fulfilling the questionnaire. From a total of 150 questionnaires, only 100 valid questionnaires received back.

\section{Sample Size}

A total of 150 questionnaires were distributed among kariyana and general stores business units and gave them time as per their demand and were requested to complete the structured questionnaire voluntarily but only 100 respondents had responded and returned the completed questionnaires. Therefore, 100 respondents are considered a valid sample for this study.

\section{Data Collection Technique and Instrument}

A well-structured and verified scale was used to gather statistics for the study. The questionnaires were circulated among the respondents working on different kariyana and general stores of Gulistan-e-Jauhar, Karachi personally by the researchers. The data were taken from kariyana and general store businesses situated in the sample areas. The majority of such entrepreneurs were less educated and lacked the importance of adequate infrastructure for entrepreneurial businesses. The data were collected in 20 days subsequently the collected data was then analysed by the statistical tools using SPSS. 


\section{Reliability Test}

In order to check the internal consistency of the tool, Cronbach's alpha was calculated. The rate of Cronbach's Alpha was 0.735. It is suggested the accepted edge of reliability should be at least 0.70 . It shows that our tool is reliable. As indicated in Table_1 and Table_2 below:

Table: 1

Case processing summary

\begin{tabular}{|l|l|r|r|}
\hline \multirow{3}{*}{ Cases } & & $\mathrm{N}$ & \multicolumn{2}{|c|}{$\%$} \\
\cline { 2 - 5 } & Valid & 100 & 100.0 \\
\cline { 2 - 4 } & Excluded & 0 & .0 \\
\cline { 2 - 4 } & Total & 100 & 100.0 \\
\hline \multicolumn{2}{|l}{ a. List wise deletion based on all variables in the procedure. } \\
\hline
\end{tabular}

Table: 2

Reliability statistics

\begin{tabular}{|c|c|}
\hline Cronbach's Alpha & N of Items \\
\hline .735 & 9 \\
\hline
\end{tabular}

\section{Data Analysis and Findings}

This section covers two parts. Part-A represents the data demographics and Part-B represents the data analysis of the study.

\section{PART-A: Data Demographics}

In this part, the demographic section of the respondents has been addressed. Here, five main areas of respondents have been checked. The records as per data collected from the study area consists of gender, age, education, experiences and strength of the respondents. The detailed discussion on these five elements have been given in the following paragraphs:

Table: 3

Statistics for demographic section

\begin{tabular}{|l|c|c|c|c|c|c|}
\hline & & Experience & Age & Gender & Education & $\begin{array}{c}\text { Number of } \\
\text { Employees }\end{array}$ \\
\hline \multirow{2}{*}{$\mathrm{N}$} & Valid & 100 & 100 & 100 & 100 & 100 \\
\cline { 2 - 7 } & Missing & 0 & 0 & 0 & 0 & 0 \\
\hline Mean & 8.0200 & 35.8200 & 1.0400 & 2.3300 & 3.6000 \\
\hline Median & 8.0000 & 34.0000 & 1.0000 & 2.0000 & 3.0000 \\
\hline Mode & 5.00 & $32.00^{\mathrm{a}}$ & 1.00 & 2.00 & 3.00 \\
\hline \multicolumn{2}{l}{ Std. Deviation } \\
\multicolumn{2}{|l|}{3.82966} & 9.52019 & .19695 & 1.07360 & 1.75810 \\
\hline
\end{tabular}


According to table_3, a very small variation occurs in mean and median, mode is slightly far other averages.

\section{Gender}

This study exclusively consists of 100 Kariyana and General Stores situated in Gulistan-e-Jauhar, Karachi comprising of 96 male owners and only 4 female owners, as shown in Figure_2. It shows that majority of male shop-keepers are running general and kariyana stores. Only 4 ladies are doing their business either partly or fully. The researchers included their responses because they have participated in data providing process. Otherwise, in Pakistani society, most of male entrepreneurs handle a general store business.

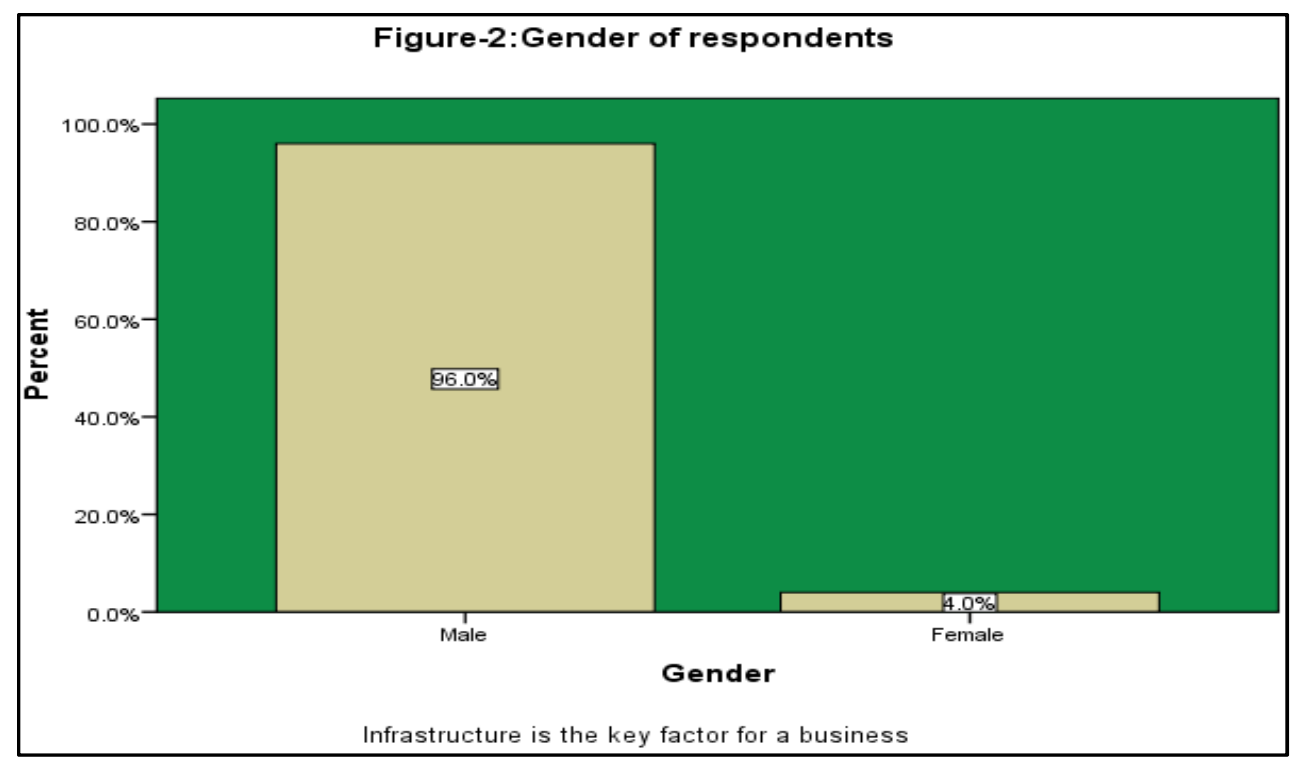

Table: 4

Gender

\begin{tabular}{|l|l|r|r|r|r|}
\hline \multirow{3}{*}{ Valid } & Male & Frequency & Percent & $\begin{array}{c}\text { Valid } \\
\text { Percent }\end{array}$ & $\begin{array}{c}\text { Cumulative } \\
\text { Percent }\end{array}$ \\
\cline { 2 - 6 } & Female & 96 & 96.0 & 96.0 & 96.0 \\
\cline { 2 - 6 } & Total & 4 & 4.0 & 4.0 & 100.0 \\
\hline
\end{tabular}

Table_ 4 confirms the information provided in figure_2, above. 
Figure_3, below depicts that the respondents in the age of 22 years are $3 \%$ of the total population. The respondents in the age of 32 years and 50 years are $7 \%$ each of the total population of the study area. In many cases, only $1 \%$ population is in a certain age bracket.

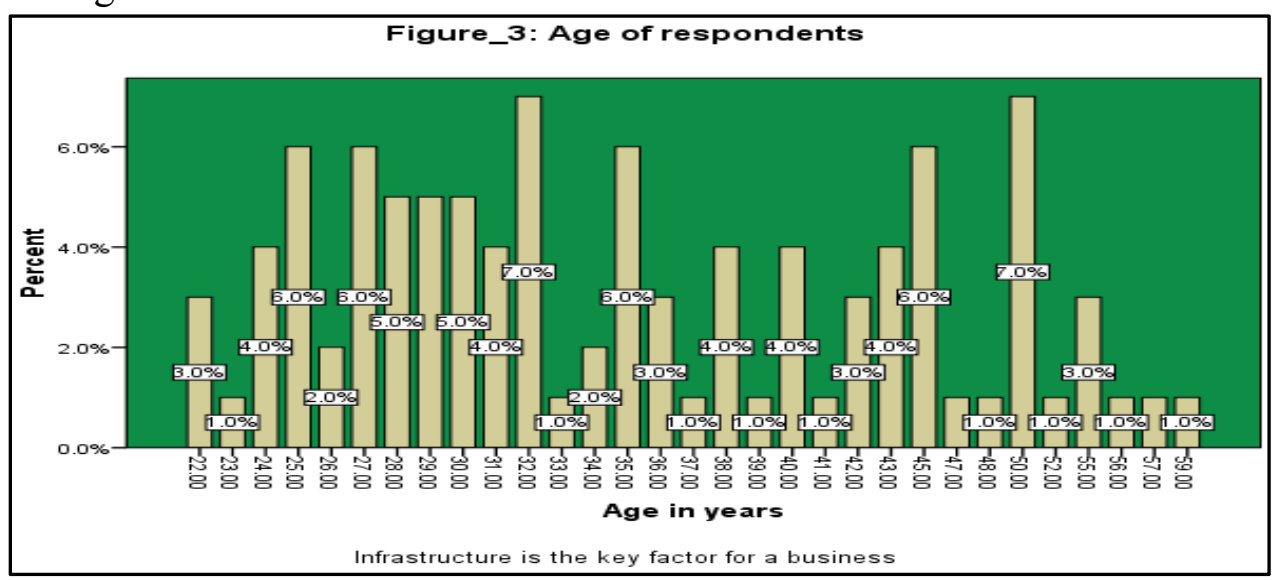

Table: 5

Age of respondents

\begin{tabular}{|c|c|c|c|c|c|}
\hline & & Frequency & Percent & $\begin{array}{l}\text { Valid } \\
\text { Percent }\end{array}$ & $\begin{array}{c}\text { Cumulative } \\
\text { Percent }\end{array}$ \\
\hline \multirow[t]{20}{*}{ Valid } & 22 & 3 & 3.0 & 3.0 & 3.0 \\
\hline & 23 & 1 & 1.0 & 1.0 & 4.0 \\
\hline & 24 & 4 & 4.0 & 4.0 & 8.0 \\
\hline & 25 & 6 & 6.0 & 6.0 & 14.0 \\
\hline & 26 & 2 & 2.0 & 2.0 & 16.0 \\
\hline & 27 & 6 & 6.0 & 6.0 & 22.0 \\
\hline & 28 & 5 & 5.0 & 5.0 & 27.0 \\
\hline & 29 & 5 & 5.0 & 5.0 & 32.0 \\
\hline & 30 & 5 & 5.0 & 5.0 & 37.0 \\
\hline & 31 & 4 & 4.0 & 4.0 & 41.0 \\
\hline & 32 & 7 & 7.0 & 7.0 & 48.0 \\
\hline & 33 & 1 & 1.0 & 1.0 & 49.0 \\
\hline & 34 & 2 & 2.0 & 2.0 & 51.0 \\
\hline & 35 & 6 & 6.0 & 6.0 & 57.0 \\
\hline & 36 & 3 & 3.0 & 3.0 & 60.0 \\
\hline & 37 & 1 & 1.0 & 1.0 & 61.0 \\
\hline & 38 & 4 & 4.0 & 4.0 & 65.0 \\
\hline & 39 & 1 & 1.0 & 1.0 & 66.0 \\
\hline & 40 & 4 & 4.0 & 4.0 & 70.0 \\
\hline & 41 & 1 & 1.0 & 1.0 & 71.0 \\
\hline
\end{tabular}




\begin{tabular}{|c|c|c|c|c|c|}
\hline \multirow{7}{*}{} & 42 & 3 & 3.0 & 3.0 & 74.0 \\
\cline { 2 - 6 } & 43 & 4 & 4.0 & 4.0 & 78.0 \\
\cline { 2 - 6 } & 45 & 6 & 6.0 & 6.0 & 84.0 \\
\cline { 2 - 6 } & 47 & 1 & 1.0 & 1.0 & 85.0 \\
\cline { 2 - 6 } & 48 & 1 & 1.0 & 1.0 & 86.0 \\
\cline { 2 - 6 } & 50 & 7 & 7.0 & 7.0 & 93.0 \\
\cline { 2 - 6 } & 52 & 1 & 1.0 & 1.0 & 94.0 \\
\cline { 2 - 6 } & 55 & 3 & 3.0 & 3.0 & 97.0 \\
\cline { 2 - 6 } & 56 & 1 & 1.0 & 1.0 & 98.0 \\
\cline { 2 - 6 } & 57 & 1 & 1.0 & 1.0 & 99.0 \\
\cline { 2 - 6 } & 59 & 1 & 1.0 & 1.0 & 100.0 \\
\cline { 2 - 6 } & Total & 100 & 100.0 & 100.0 & \\
\hline
\end{tabular}

Table_5 indicates the frequency of male and female entrepreneurs with their age brackets working on different general and kariyana stores in Gulistan e Jauhar, Karachi.

\section{Education}

Figure 4 represents the age of respondents. Accordingly, 26\% persons were nonmatric, $34 \%$ shop-keepers were the only matric, $22 \%$ respondents were intermediate, $17 \%$ were graduate and only $1 \%$ respondents were post-graduates entrepreneurial business owners in the sample area. It shows that this business needs not higher education, a reasonable education is enough to run this business.

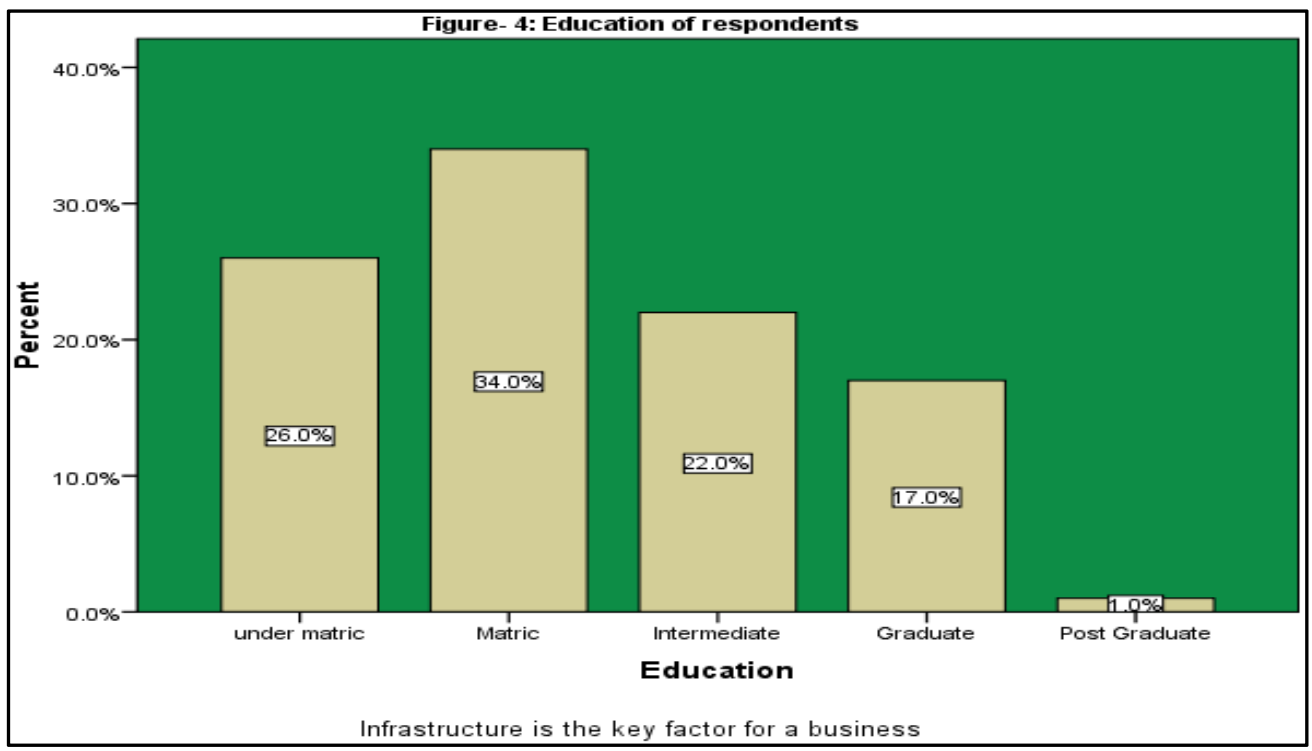


Table: 6

Education

\begin{tabular}{|l|l|c|c|c|c|}
\hline & & Frequency & Percent & $\begin{array}{c}\text { Valid } \\
\text { Percent }\end{array}$ & $\begin{array}{c}\text { Cumulative } \\
\text { Percent }\end{array}$ \\
\hline Valid & under matric & 26 & 26.0 & 26.0 & 26.0 \\
\cline { 2 - 6 } & Matric & 34 & 34.0 & 34.0 & 60.0 \\
\cline { 2 - 6 } & Intermediate & 22 & 22.0 & 22.0 & 82.0 \\
\cline { 2 - 6 } & Graduate & 17 & 17.0 & 17.0 & 99.0 \\
\cline { 2 - 6 } & Post Graduate & 1 & 1.0 & 1.0 & 100.0 \\
\cline { 2 - 6 } & Total & 100 & 100.0 & 100.0 & \\
\hline
\end{tabular}

Table_6 indicates the education level of entrepreneurs in the sample area.

\section{Experience}

Figure_5: depicts the experiences of respondents in the sample area. Accordingly, some shop-keepers are new in this field and they simply experience of 2 years, 3 years and 4 years but $14 \%$ respondents have the experience of 5 years. Similarly, $13 \%$ respondents have 8 years of experience in the field and $2 \%$ of the respondents have 17 years of experience in the field of running the general store business in the study area and they all of the respondents shared their responses regarding the importance of infrastructure for an entrepreneurial business.

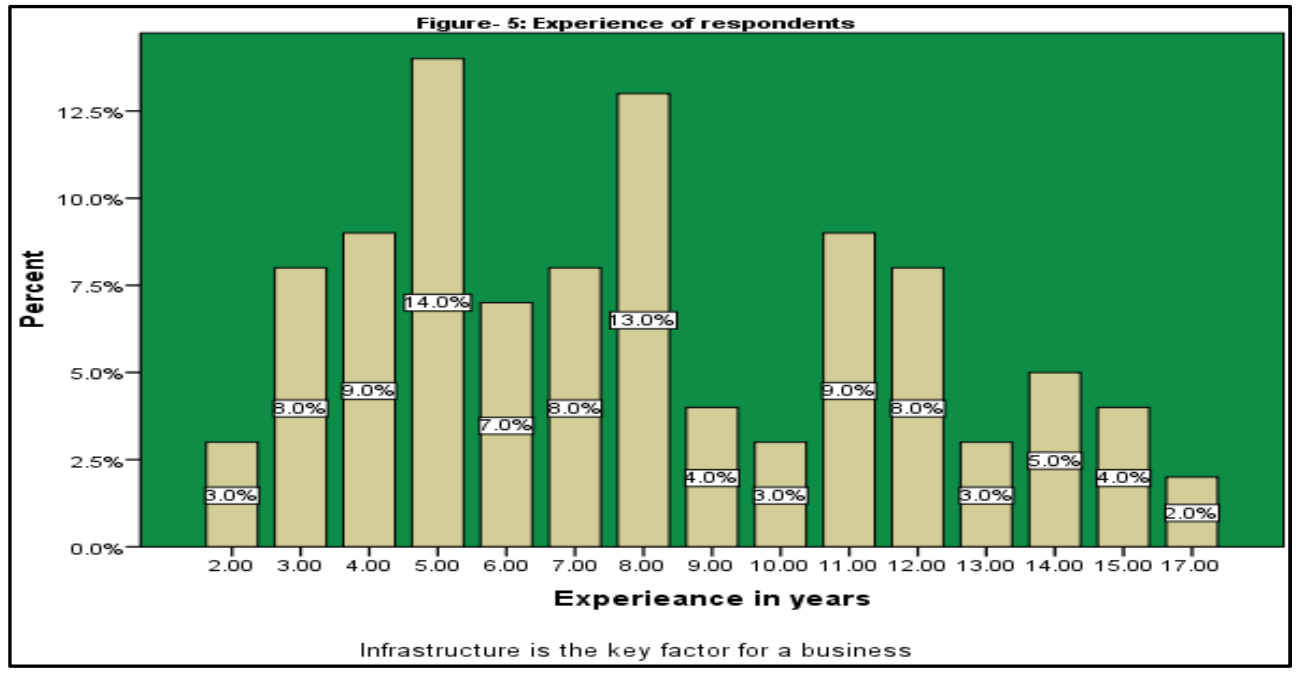


Table: 7

Experience

\begin{tabular}{|l|c|c|c|c|c|}
\hline & & Frequency & Percent & Valid Percent & Cumulative Percent \\
\hline Valid & 2 & 3 & 3.0 & 3.0 & 3.0 \\
\cline { 2 - 6 } & 3 & 8 & 8.0 & 8.0 & 11.0 \\
\cline { 2 - 6 } & 4 & 9 & 9.0 & 9.0 & 20.0 \\
\cline { 2 - 6 } & 5 & 14 & 14.0 & 14.0 & 34.0 \\
\cline { 2 - 6 } & 6 & 7 & 7.0 & 7.0 & 41.0 \\
\cline { 2 - 6 } & 7 & 8 & 8.0 & 8.0 & 49.0 \\
\cline { 2 - 6 } & 8 & 13 & 13.0 & 13.0 & 62.0 \\
\cline { 2 - 6 } & 9 & 4 & 4.0 & 4.0 & 66.0 \\
\cline { 2 - 6 } & 10 & 3 & 3.0 & 3.0 & 69.0 \\
\cline { 2 - 6 } & 11 & 9 & 9.0 & 9.0 & 78.0 \\
\cline { 2 - 6 } & 12 & 8 & 8.0 & 8.0 & 86.0 \\
\cline { 2 - 6 } & 13 & 3 & 3.0 & 3.0 & 94.0 \\
\cline { 2 - 6 } & 14 & 5 & 5.0 & 5.0 & 98.0 \\
\cline { 2 - 6 } & 15 & 4 & 4.0 & 4.0 & 100.0 \\
\cline { 2 - 6 } & 17 & 2 & 2.0 & 2.0 & \\
\cline { 2 - 6 } & Total & 100 & 100.0 & 100.0 & \\
\hline
\end{tabular}

Table 7 indicates of the experience of the respondents with the relevant percentages of levels.

\section{Strength (Number of Respondents)}

A total of 100 general stores are running in the sample area. The distribution of working persons in different Kariyana and General stores are shown by figure_6, below:

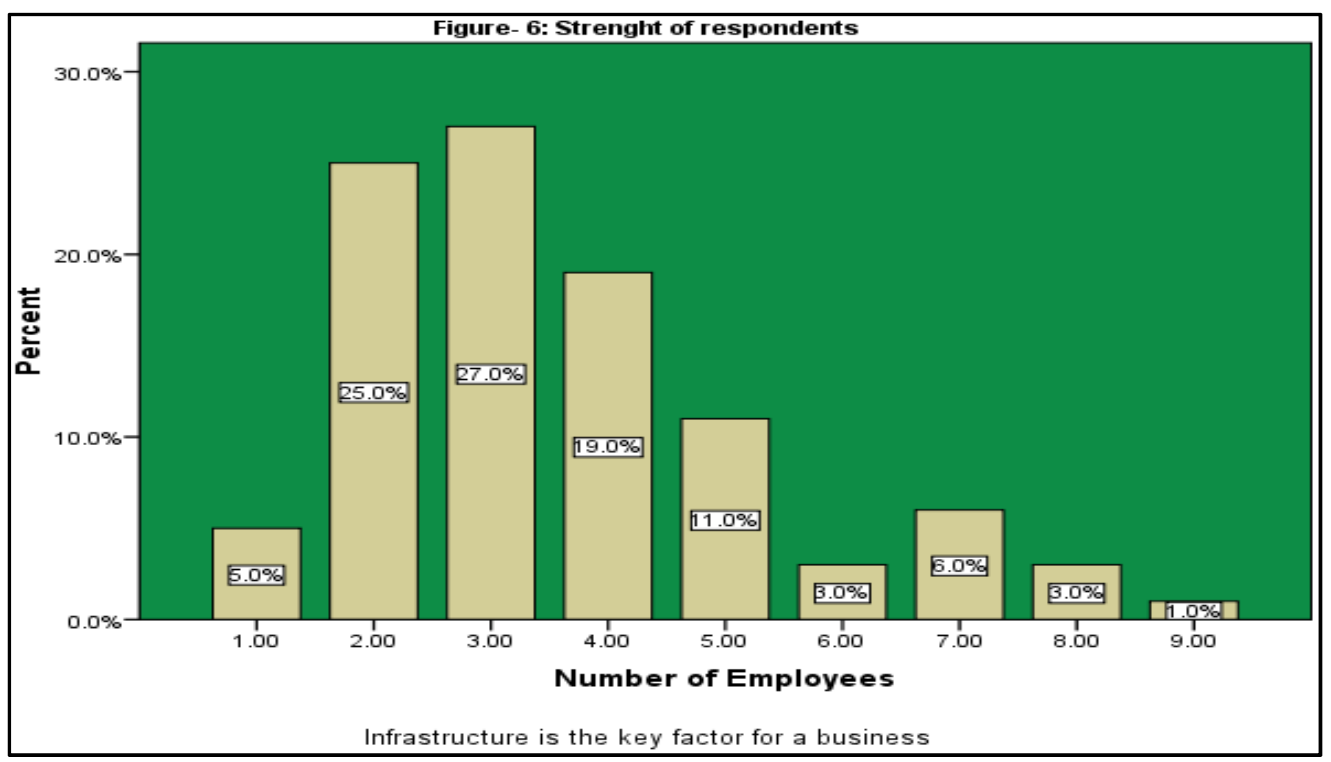


Accordingly, 5\% shops are run by a single person only, $25 \%$ by 2 persons, $27 \%$ by 3 persons, $19 \%$ by 4 persons, $11 \%$ by 5 persons, $3 \%$ by 6 persons, $8 \%$ by 7 persons, $3 \%$ by 8 persons and $1 \%$ by 9 persons. Definitely, those shops that are run by more than one persons are enjoying their business on large scale and the responses from all of these persons will be considered as a big contribution for this research.

Table: 8

Number of employees

\begin{tabular}{|l|c|c|c|c|c|}
\hline \multirow{4}{*}{ Valid } & Frequency & Percent & $\begin{array}{c}\text { Valid } \\
\text { Percent }\end{array}$ & $\begin{array}{c}\text { Cumulative } \\
\text { Percent }\end{array}$ \\
\cline { 2 - 6 } & 1 & 5 & 5.0 & 5.0 & 5.0 \\
\cline { 2 - 6 } & 2 & 25 & 25.0 & 25.0 & 30.0 \\
\cline { 2 - 6 } & 3 & 27 & 27.0 & 27.0 & 57.0 \\
\cline { 2 - 6 } & 4 & 19 & 19.0 & 19.0 & 76.0 \\
\cline { 2 - 6 } & 5 & 11 & 11.0 & 11.0 & 87.0 \\
\cline { 2 - 6 } & 6 & 3 & 3.0 & 3.0 & 90.0 \\
\cline { 2 - 6 } & 7 & 6 & 6.0 & 6.0 & 96.0 \\
\cline { 2 - 6 } & 8 & 3.0 & 3.0 & 99.0 \\
\cline { 2 - 6 } & 9 & 1 & 1.0 & 1.0 & 100.0 \\
\hline
\end{tabular}

Table_ 8 indicates the number of employees (shop-keepers) with the frequencies of working places in the sample areas.

\section{Part-B: Data Analysis}

This section of analysis covers with the help of figures that indicate analysis was done by the Statistical Package for Social Sciences (SPSS) and the resultant results have been discussed accordingly.

\section{Infrastructure}

Infrastructure means the basic physical and organizational structures and facilities (e.g. buildings, roads, power supplies) needed for the operation of a society or enterprise (Adl-Zarrabi, 2017).

\section{Building Area}

The general store or shop areafor the business must be easily approachable for general public without facing any problem regarding parking, entering and exit etc. 


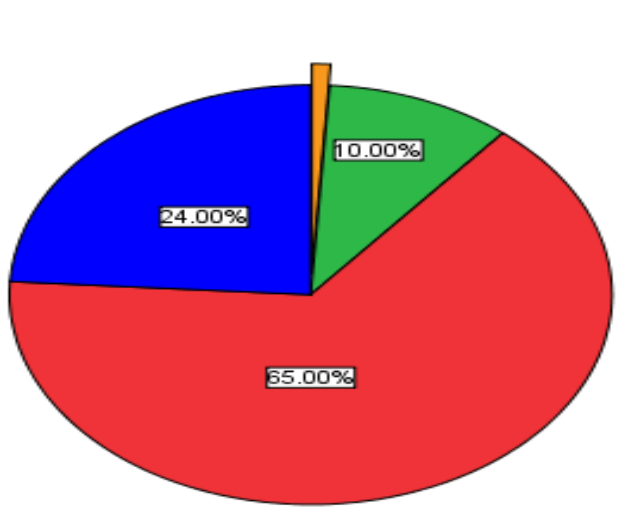

According to the descriptive analysis of the data gathered from the respondents of the sample population and their results as per Likert scale analysis are shown in figure_7. Accordingly, $24.00 \%$ of respondents strongly agreed and $65.00 \%$ of respondents agreed with the alternate hypothesis while $10 \%$ of respondents remained neutral and $1 \%$ of respondents have disagreed with the alternate hypothesis.

\section{Roads Alongside}

The roads or streets alongside the business area must be clear from any barrier or blockage so that the general public can easily move during shopping time.

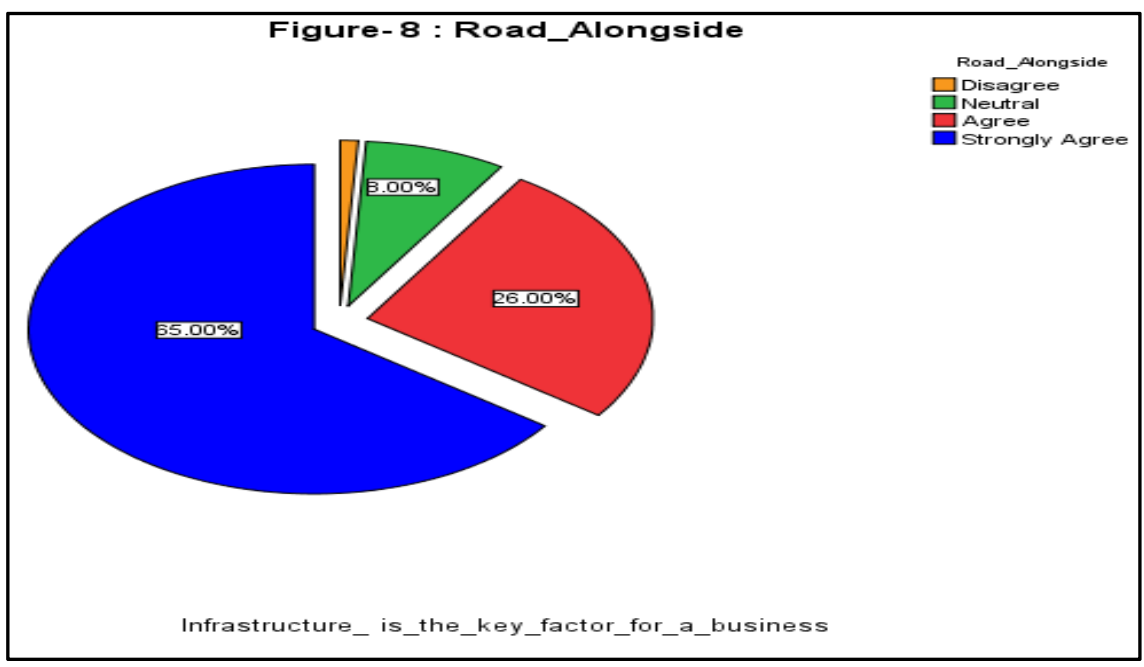


According to the descriptive analysis of the data gathered from the respondents of the sample population and their results as per Likert scale analysis are shown in figure_8. Accordingly, $65.00 \%$ of respondents strongly agreed and $26.00 \%$ of respondents agreed with the alternate hypothesis while $8 \%$ of respondents remained neutral and $1 \%$ of respondents have disagreed with the alternate hypothesis.

\section{Power Supplies}

Power supplies act as the backbone as well as the lubricant for a speedy business. Therefore, there must be proper arrangement of electricity, gas and water as per need of the entrepreneurial business.

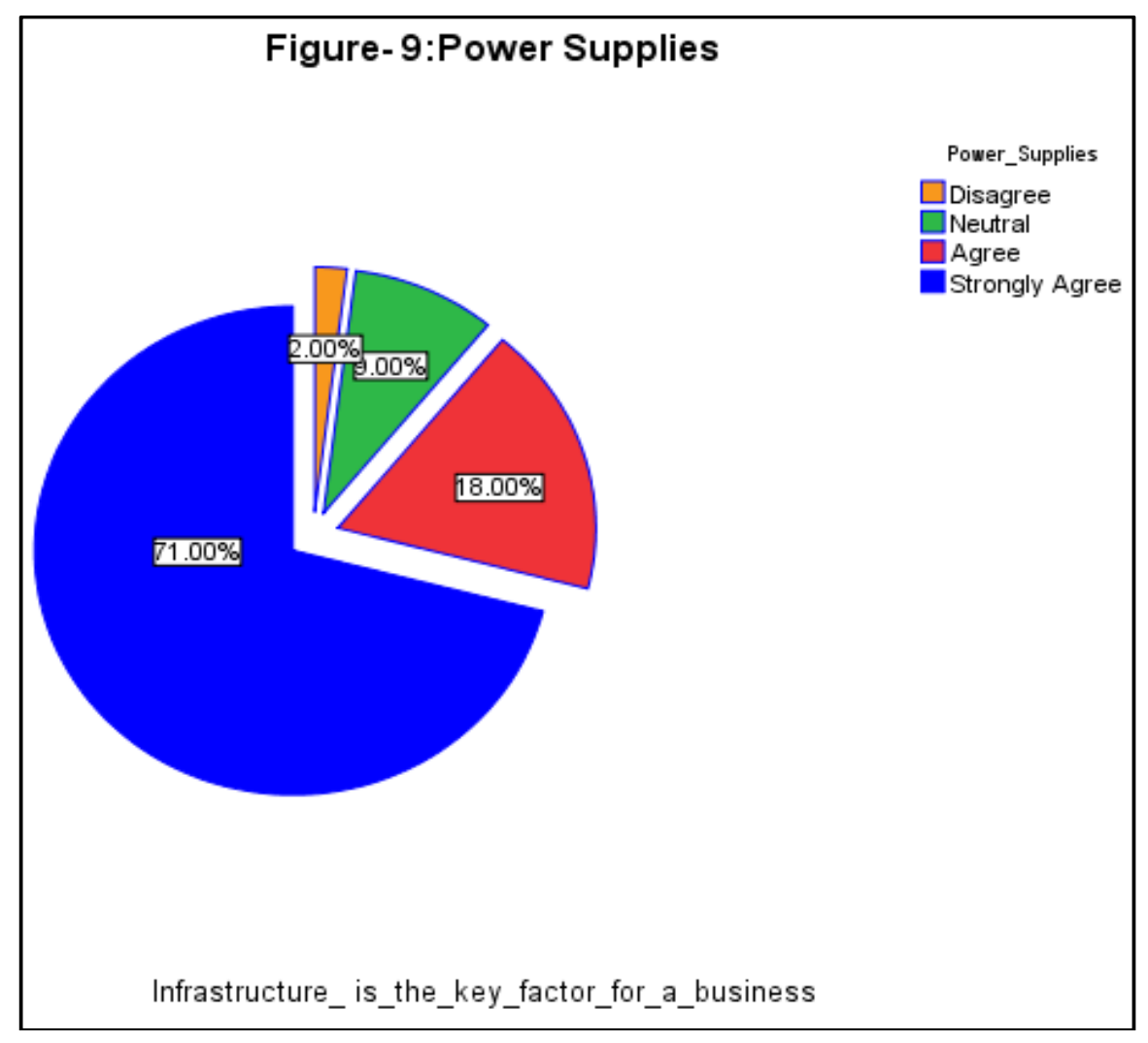

According to the descriptive analysis of the data gathered from the respondents of the sample population and their results as per Likert scale analysis are shown in figure_9. Accordingly, $71.00 \%$ of respondents strongly agreed and $18.00 \%$ of respondents agreed with the alternate hypothesis while $9 \%$ of respondents remained neutral and $2 \%$ of respondents have disagreed with the alternate hypothesis. 


\section{Secured Place}

A secured business area is more preferred for the potential customers. People like the secured places and visit them frequently without any tension.

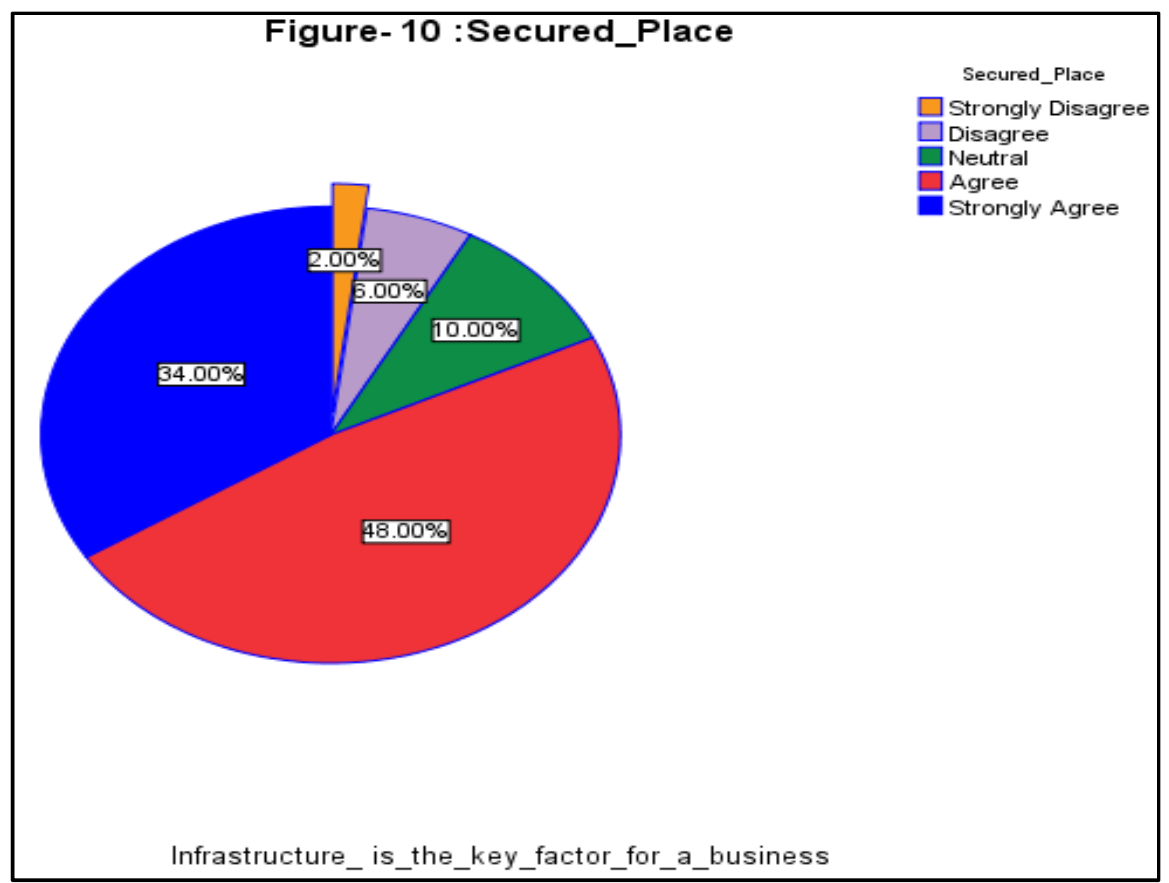

According to the descriptive analysis of the data gathered from the respondents of the sample population and their results as per Likert scale analysis are shown in figure_10. Accordingly, 34.00\% of respondents strongly agreed and $48.00 \%$ of respondents agreed with the alternate hypothesis while $10 \%$ of respondents remained neutral, $8 \%$ of respondents disagreed with our concept and $2 \%$ of the respondents have disagreed with the alternate hypothesis.

\section{Conclusions}

Based on data analysis and discussionand after developing the necessary analyses for each investigated element, we conclude that there is a relationship between the proposed model (adequate infrastructure) and entrepreneurial business activity.It concludes that for improvement in selling activities of a shop keeper, having of the adequate infrastructure is considered as a key factor for the success of any business. It depends upon the visible and invisible sub-factors that have been explained as follows: 


\section{Building Area}

The general store or shop area for an entrepreneurial business must be built in such a way that it must be in easy access to the general public without any problem of parking, entry, or exit from such area. People visit such business places more frequently where they feel ease and secured.

\section{Roads Alongside}

The roads or streets attached to the business area must be clear from any type of difficulty in the movement of the general public during their shopping hours.In big cities like Karachi the majority of people remain in a problem of short of time. They want to perform more home responsibilities in less time. Therefore, such places which show less disturbance for general public in their movement, they are more beneficial for business point of view.

\section{Power Supplies}

A smoothly running power supply facilities must be available for uninterrupted ongoing transactions of a business. Therefore, it is the core duty of an entrepreneur that the timely availability of electricity, gas, and water for business requirements must be ensured. Normally, families go for shopping with their kids and with old age people and if business places have a proper power supply arrangements, people visit such places with full confidence. They purchase their maximum households from such general and kariyana stores.

\section{Secured Place}

People prefer secured shopping areas for their shopping. It is, therefore, the utmost responsibility of an entrepreneur that the business place must be safe, and there must be arrangements of proper security system so that actual, as well as potential customers, may visit the shopping area without any fear. Life is the most precious thing of the world that is why people prefer those general and kariyana stores where there is a proper security arrangements so that people may visit such places without any fear and tension.

\section{Recommendations}

The proposed recommendations for the study are:

1. Based on the results achieved from the analysis, having the adequate infrastructure is considered as a key factor for the success of an entrepreneurial business because the sub-factors of infrastructure such as 
building area, roads alongside the business place, power supplies and security system for such business are very important for achieving the business targets.

2. The availability of adequate infrastructure is justified to recommend for kariyana and general store business because it increases the initial cost of business but later on, it gives the positive results to achieve the business targets easily. In other words, it is said that adequate business infrastructure not only necessary for increasing business activities but also saves the hidden cost that a business person has to bear in case of failure of any business due to improper business infrastructure.

\section{References}

Acs, Z. \& Varga, A. (2004). Entrepreneurship, Agglomeration and Technological Change. Max-Plank Institute for Research into Economic System, (July), 27.

Adisa, T., Abdulraheem, I. \& Mordi, C. (2014). The Characteristics and Challenges of Small Businesses in Africa: An Exploratory Study of Nigerian Small Business Owners. Economic Insights-Trends and Challenges, vol.111:4, pp.1-14.

Adl-Zarrabi, B. (2017). What is "Infrastructure Physics"? Energy Procedia, 132 (January 2003), 520-524. https://doi.org/10.1016/j.egypro.2017.09.707

Agwu, M. O. \& Cletus Izunwanne Emeti. (2014). Issues, Challengesand Prospectsof Small and Medium Scale Enterprises (SMEs) in Port-Harcourt City,. European Journal of Sustainable Development, vol.3:1, pp.101-114. https://doi.org/10.14207/ejsd.2014.v3n1p101

Ahammad, I. \& Moudud-Ul- Huq. (2013). Women Entrepreneurship Development in Bangladesh Challenges And Prospects. International Journal of Innovative Research \& Development, vol.2:7, pp.41-48.

Akinyele, S. T. (2019). Infrastructurial Development as Predictor to Small \& Medium Enterprises Performance in Nigeria. Journal of Chemical Information and Modeling, vol.53:9, pp.1-24. https://doi.org/10.1017/CBO9781107415324.004

Aktar, S. (2016). Factors Influencing Entrepreneurs. Business Performance in Small and Medium Businesses: Comparative Analysis Between Demographic and Environmental Factors in Bangladesh. Journal of Business and Technology (Dhaka), vol.10:2, pp.1-17. https://doi.org/10.3329/jbt.v10i2.29464 
Alauddin, M. \& Chowdhury, M. M. (2015). Small and Medium Enterprise in Bangladesh-Prospects and Challenges. Global Journal of Management and Business Research: C Finance, vol.15:7, p.11.

Aldrich, H. E. \& Ruef, M. (2006). Organizations evolving. Organizations Evolving, Second Edition. https://doi.org/10.4135/9781446212509

Alhorani, A. (2019). The Success Factors of and Barriers Faced by Entrepreneurial SMEs in Jordon. The Journal of Social Sciences Research, vol.5:8, pp.1265-1271. https://doi.org/10.32861/jssr.58.1265.1271

Aschauer, D. A. (1990). Why is infrastructure important? Transportation Research Board, pp.21-68.

Audretsch, D. \& Sarkar, and M. (2010). Knowledge Spillovers and Strategic Entrepreneurship. Strategic Entrepreneurship Journal, vol.1:4, pp.271-283. https://doi.org/10.1002/sej

Basil Anthony Ngwu Onugu. (2005). Small and Medium Enterprises (SMEs) in Nigeria: Problems and Prospects. Management department. St. Clements University.

Bennett, D. L. (2019). Infrastructure Investments and Entrepreneurial Dynamism in the U.S. Journal of Business Venturing, vol.34:5, p.105907. https://doi.org/10.1016/j.jbusvent.2018.10.005

Carree, M. A. \& Verheul, I. (2011). What Makes Entrepreneurs Happy? Determinants of Satisfaction Among Founders. Open Access at Springerlink.Com, 17. https://doi.org/10.1007/s10902-011-9269-3

Chowdhury, F., Audretsch, D. B. \& Belitski, M. (2019). Institutions and Entrepreneurship Quality. Entrepreneurship: Theory and Practice, vol.43:1, pp.51-81. https://doi.org/10.1177/1042258718780431

Cumming, D. J. \& Zahra, S. A. (2016). International Business and Entrepreneurship Implications of Brexit. British Journal of Management, vol.27:4, pp.687-692. https://doi.org/10.1111/1467-8551.12192

Diana Rusu, V. \& Roman, A. (2017). Entrepreneurial Activity in the EU: An Empirical Evaluation of its Determinants. Sustainability (Switzerland), vol.9:10, pp.1-16. https://doi.org/10.3390/su9101679 
Estrin, S. \& Mickiewicz, T. (2011). Institutions and Female Entrepreneurship. Small Business Economics, vol.37:4, pp.397-415. https://doi.org/10.1007/ s11187-011-9373-0

George, G., Rao-Nicholson, R., Corbishley, C. \& Bansal, R. (2015). Institutional Entrepreneurship, Governance and Poverty: Insights from Emergency Medical Response Servicesin India. Asia Pacific Journal of Management, vol.32:1, pp.39-65. https://doi.org/10.1007/s10490-014-9377-9

Greenwood, R., Oliver, C., Lawrence, T., Meyer, R., Hinings, C. R. (Bob), Logue, D. \& Zietsma, C. (2018). Fields, Institutional Infrastructure and Governance. The SAGE Handbook of Organizational Institutionalism. https://doi.org/10.4135/9781446280669.n7

Grimaldi, R. \& Grandi, A. (2005). Business Incubators and New Venture Creation: An Assessment of Incubating Models. Technovation, vol.25:2, pp.111-121. https://doi.org/10.1016/S0166-4972(03)00076-2

Haque, N. U. (2007). Entrepreneurship in Pakistan. PIDE Working Papers, http://www.pide.org.pk/pdf/Working\%20Paper/WorkingPaper-29.pdf

Laclé, F. A. (2010). Entrepreneurship, Economic Development and the Barriers in Between, http://arno.uvt.nl/show.cgi?fid=121035

Lee, S. H., Yamakawa, Y., Peng, M. W., \& Barney, J. B. (2011). How do Bankruptcy Laws Affect Entrepreneurship Development Around the World? Journal of Business Venturing, vol.26:5, pp.505-520. https://doi.org/10.1016/j.jbusvent.2010.05.001

Lugo, J. E. B. \& Espina, M. I. (2014). Determinant Factors for the Development of Entrepreneurial Activity: A Correlational Study. Esic Market Economics and Business Journal, vol.45:1, pp.147-160. https://doi.org/10.7200/ esicm.147.0451.4i

Mahanta, M., \& Dr. Parbin Sultana. (2018). International Journal of Trend in Scientific Research and Development ( IJTSRD ) Infrastructure Facility a and nd Entrepreneurship Development Developm Among Women - A Case Study o of Sonitpur District of $\mathrm{f}$ Assam. International International Journal of Trend in Scientific Research Research and Development (IJTSRD), vol.2:4, pp.2634-2644.

Mccoy, D., Lyons, S., Morgenroth, E., Palcic, D., \& Allen, L. (2016). The impact of local infrastructure on new business establishments. Munich Personal RePEc Archive, (69074), 26. 
Mutsuddi, I. (2016). Role of infrastructural growth for entrepreneurial development: A study in Durgapur. Delhi School of Professional Studies \& Research. Delhi: http://www.internationalseminar.in/XVII_AIS/INDEX.HTM.

Rani, J., \& Sinha, S. K. (2016). Barriers Facing Women Entrepreneurs in Rural India : A Study in Haryana. Amity Journal of Entrepreneurship, vol.1:1.

Sabbarwal, S. (2010). Factors Affecting New Venture Creation: A Stuy in Indian Scenario. International Journal of Business and Management Studies, vol.2:1, pp.81-88.

Sitharam, S. \& Hoque, M. (2016). Factors Affecting the Performance of Small and Medium Enterprises in KwaZulu-Natal, South Africa. Problems and Perspectives in Management, vol.14:2, pp.226-288. https://doi.org/ 10.21511/ppm.14(2-2).2016.03

Stephan, U. \& Uhlaner, L. M. (2010). Performance-Based vs Socially Supportive Culture: A Cross-National Study of Descriptive Norms and Entrepreneurship. Journal of International Business Studies, vol.41:8, pp.1347-1364. https://doi.org/10.1057/jibs.2010.14

Thurik, A. R., Stam, E. \& Audretsch, D. B. (2013). The Rise of the Entrepreneurial Economy and the Future of Dynamic Capitalism. Technovation, vol.33:8-9, pp.302-310. https://doi.org/10.1016/ j.technovation.2013.07.003

Woolley, J., \& Woolley, J. (2017). Infrastructure for Entrepreneurship. Oxford Research Encyclopedia of Business and Management, (August), 23. https://doi.org/10.1093/acrefore/9780190224851.013.33 


\title{
APPENDIX
}

\section{CLOSED ENDED QUESTIONNAIRES - APPENDIX-A}

\begin{abstract}
SURVEY QUESTIONNAIRE (English)
Infrastructure is a key factor for the success of an entrepreneurial business:" A case study of general store business in Gulistan-e-Jauhar, Karachi”.

Dear Respondent:

We, are researchers associated with renowned universities, want to conduct a research on the aforementioned topic (An article) and We are in the process of data collection. You are requested to spare your few precious minutes for filling out the questionnaire in your hand. The information provided by you will be used purely for academic purpose and We will maintain confidentiality of your opinion expressed for this research. Thank you for cooperation and your time.
\end{abstract}

Name:

\section{SECTION ONE-BASIC INFORMATION}

Age: ___ years Gender: Male/Female/Other

Education: Under Matric/Matric/Intermediate/Graduate/Post Graduate Nature of Business: Bakery \& Confectionery Business

Established Since: ___ years ___ Number of employees: persons

Business Name \& Address:

\section{SECTION-TWO- Adequate Infrastructure}

Please encircle one number per statement to indicate your view towards the given questions, where 1 means that you strongly disagree, 2 means that you disagree, 3 means that you are neutral, 4 means that you agree, and 5 means that you strongly agree.

\begin{tabular}{|c|c|c|c|c|c|c|}
\hline S.No & Entrepreneurial Business v/s Adequate Infrastructure & & $\mathbf{u r}$ & $\mathrm{Cl}$ & oic & \\
\hline 1 & $\begin{array}{l}\text { Proper infrastructure is essential for } \\
\text { ageneral store. }\end{array}$ & 5 & 4 & 3 & 2 & 1 \\
\hline 2 & An attractive business place plays a key role for a business. & 5 & 4 & 3 & 2 & 1 \\
\hline 3 & $\begin{array}{l}\text { People like a business situated on road facing and on a } \\
\text { visible area. }\end{array}$ & 5 & 4 & 3 & 2 & 1 \\
\hline 4 & $\begin{array}{l}\text { People frequently visit that business area that is without any } \\
\text { barriers. }\end{array}$ & 5 & 4 & 3 & 2 & 1 \\
\hline 5 & $\begin{array}{l}\text { Business places with attractive infrastructures save } \\
\text { customers' time. }\end{array}$ & 5 & 4 & J & 2 & 1 \\
\hline
\end{tabular}




\begin{tabular}{|l|l|l|l|l|l|l|}
\hline 6 & $\begin{array}{l}\text { General stores with proper lighting are visited more by the } \\
\text { customers. }\end{array}$ & 5 & 4 & 3 & 2 & 1 \\
\hline 7 & $\begin{array}{l}\text { The proper parking are for a business may } \\
\text { attractmorepotential buyers. }\end{array}$ & 5 & 4 & 3 & 2 & 1 \\
\hline 8 & $\begin{array}{l}\text { People like that shop where proper security system is } \\
\text { available. }\end{array}$ & 5 & 4 & 3 & 2 & 1 \\
\hline 9 & $\begin{array}{l}\text { People prefer a shopping area with maximum customers' } \\
\text { facilities. }\end{array}$ & 5 & 4 & 3 & 2 & 1 \\
\hline
\end{tabular}

Muhammad Siddique is an Assistant Professor in the PN School of Logistics, PNS Karsaz, Karachi, Pakistan.

Dr. Faraz Ahmed Wajidi is an Associate Professor in the Institute of Business and Health Management (IBHM), Dow University of Health Sciences, Karachi, Pakistan.

Mrs. Eruj Wajidi is Lecturer in the Institute of Health \& Business Management (IOHBM), Jinnah Sindh Medical University (JSMU) Karachi, Pakistan. 